\title{
Workshop Penulisan Proposal Penelitian Tindakan Kelas untuk Guru di SMA Negeri 2 Paloh Kabupaten Sambas
}

\author{
Imran*1, Izhar Salim² ${ }^{2}$ Stella Prancisca ${ }^{3}$, Nining Ismiyani ${ }^{4}$, \\ Iwan Ramadhan', Edwin Mirzachaerulsyah ${ }^{6}$
}

\author{
1,2,3,4,5,6Program Studi Pendidikan Sosiologi, Fakultas Keguruan dan Ilmu Pendidikan, \\ Universitas Tanjungpura, Indonesia \\ *e-mail: $\underline{\text { imran@fkip.untan.ac.id }}^{1}$
}

\begin{abstract}
Abstrak
Pendidikan termasuk kedalam salah satu aspek penting dalam kehidupan terutama bagi setiap individu yang ada. Hal ini dikarenakan dalam kehidupan sehari-hari diperlukannya sumber daya manusia yang lebih baik agar manusia memiliki kapasitasnya masing-masing terutama pada perkembangan di era global dan persiaingan yang ketat pada saat ini, oleh sebab itu diperlukannya pengembangan keterampilan, terutama bagi pendidik yang akan mendidik setiap peserta didik untuk menjadi lebih baik. Penelitian Tindakan Kelas (PTK) merupakan salah satu wujud dalam membantu guru untuk mengatasi dan memperbaiki proses pembelajaran yang terjadi di kelas. Dalam implementasi PTK, dimana agar materi mengenai PTK disampaikan kepada guru, perlu adanya sosialisasi, salah satunya sosialisasi dosen kepada guru mengenai workshop Penelitian Tindakan Kelas. Upaya ini dilakukan sebagai wujud dosen dalam melaksanakan Tri Dharma Perguruan Tinggi salah satunya di bidang pengabdian kepada masyarakat.
\end{abstract}

Kata kunci: Dosen, Guru, Pendidikan, Penelitian Tindakan Kelas, Pengabdian, Tri Dharma

Education is one of the important aspects of life, especially for every individual. This is because in everyday life better human resources are needed so that humans have their respective capacities, especially in developments in the global era and today's tight competition, therefore skills development is needed, especially for educators who will educate every student. students to be better. Classroom Action Research (CAR) is one form of helping teachers to overcome and improve the learning process that occurs in the classroom. In the implementation of CAR, where material about CAR is conveyed to teachers, there needs to be socialization, one of which is lecturer socialization to teachers regarding Classroom Action Research workshops. This effort is carried out as a form of lecturers in implementing the Tri Dharma of Higher Education, one of which is in the field of community service.

Keywords: Classroom Action Research, Education, Lecturer, Service, Teacher, Tri Dharma

\section{PENDAHULUAN}

Pendidikan merupakan aspek yang sangat penting bagi perkembangan sumber daya manusia, sebab pendidikan merupakan wahana atau salah satu instrumen yang digunakan bukan saja membebaskan manusia dari keterbelakangan, melainkan juga dari kebodohan dan kemiskinan. Pendidikan diyakini mampu menanamkan kapasitas baru bagi semua orang untuk mempelajari pengetahuan dan ketrampilan baru sehingga dapat diperoleh manusia produktif. Semakin ketatnya persaingan di era global dan tuntunan persaingan di dunia kerja, sangat dibutuhkan sumber daya manusia yang memiliki ketrampilan dan mampu membangun dirinya sendiri serta bersama - sama bertanggung jawab atas pembangunan bangsa. Kemajuan suatu bangsa dimasa akan datang sangatlah tergantung pada mutu pendidikan generasi muda saat ini, karena pemuda adalah ujung tombak dari kesuksesan suatu negara.

Penelitian Tindakan Kelas (PTK) merupakan salah satu keterampilan yang idealnya dimiliki oleh setiap guru. Hal ini disebabkan karena PTK dimaksudkan untuk membantu guru mengatasi dan memperbaiki proses pembelajaran di kelas. Guru merupakan orang yang paling menganal kelasnya dan interaksi yang terjadi antara guru-siswa berlangsung secara unik. Keterlibatan guru dalam berbagai kegiatan kreatif dan inovatif yang bersifat pengembangan memsyaratkan guru mampu melakukan PTK. Masalah PTK diangkat dari masalah yang 
dirasakan sendiri oleh guru dalam pembelajaran. Masalah tersebut pada umumnya terkait dengan proses dan hasil belajar siswa yang tidak sesuai dengan harapan guru atau halhal lain yang berkaitan dengan perilaku mengajar guru dan perilaku belajar siswa. Langkah menemukan masalah dilanjutkan dengan menganalisis dan merumuskan masalah, kemudian merencanakan PTK dalam bentuk tindakan perbaikan, mengamati, dan melakukan refleksi (Barnawi, 2019). Pada PTK, guru bertindak sebagai pengajar sekaligus peneliti. Fokus penelitian ini adalah kegiatan pembelajaran Guru memiliki otonomi dalam mengajar, termausk juga dalam merefleksikan dna mengavlausi proses dna haisl belajar. Metode paling utama adalah merefleksikan diri adalah dengan mengikuti kaidah-kaidah penelitian yang sudah baku. Salah satunya dengan melakukan PTK. Ada banyak manfaat PTK bagi guru, misalnya membantu guru memperbaiki mutu pembelajaran, meningkatkan profesionalitas guru, meningkatkan rasa percaya diri guru, serta memungkinkan guru secara aktif mengembangkan pengetahuan dan keterampilan. Disamping itu, dengan melakukan PTK maka guru menjadi terbiasa menulis dan sangat baik akibatnya bila guru sekolah negeri, khususnya dari gol. IVA ke IVB yang mengharuskan guru untuk menuliskan karya tulis ilmiah. Masalah utama adalah masih rendahnya kemampuan guru untuk melakukan PTK karena guru belum terbiasa memecahkan masalah pembelajaran melalui pendekatan penelitian, terutama penelitian tindakan kelas. Mengingat pentingnya PTK bagi guru maka diperlukan pelatihan dan pembimbingan PTK bagi guru (Febrilia et al, 2020).

Kegiatan ini dilakukan sebagai bagian dari kegiatan pengabdian kepada masyarakat (PKM) dosen Prodi Pendidikan Sosiologi, FKIP, Universitas Tanjungpura yang memiliki kepakaran dan keterampuilan untuk melaksanakannya. Idealnya, workshop dan pembimbingan dilakukan dalam periode satu semester, mengikuti pelaksanaan proses pembelajaran sehingga guru memiliki bekal yang cukup untuk bisa menerapan PTK setelah kegiatan platihan dan pembimbingan dilakukan. Meskipun demikian mengingat keperbatasan waktu pelaksanaan kegiatan, PKM dilakukan dengan menggunakan contoh produk PTK guru yang sudah pernah mengambil matakuliah PTK. Pengalaman guru yang sudah mengambil matakuliah PTK beserta produk yang dihasilkannya dimanfaatkan untuk memberi contoh bagi guru lain bahwa PTK bisa dilakukan dan melalui kegiatan PKM ini dapat ditunjukkan bahwa hasil PTK dapat digunakan untuk meningkatkan kualitas pembelajaran. Tujuan dari kegiatan PKM ini adalah meningkatkan pemahaman guru mengenai PTK dan meningkatkan kompetensi guru dalam mengembangkan proposal PTK. Manfaat kegiatan PKM ini adalah didapatnya peningkatan pemahaman guru mengenai PTK dan diselesaikannya proposal PTK.

Penelitian Tindakan Kelas merupakan pengembangan dari penelitian tindakan (Jaedun, 2011). Penelitian tindakan (action research) dikembangkan dengan tujuan untuk mencari penyelesaian terhadap masalah sosial. Penelitian tindakan diawali dengan kajian terhadap suatu masalah secara sistematis. Hasil kajian ini dijadikan dasar untuk menyusun suatu rencana kerja (tindakan) sebagai upaya untuk mengatasi masalah tersebut. Kegiatan berikutnya adalah pelaksanaan tindakan dilanjutkan dengan observasi dan evaluasi. Hasil observasi dan evaluasi digunakan sebagai masukkan melakukan refleksi atas apa yang terjadi pada saat pelaksanaan tindakan. Hasil refleksi kemudian dijadikan landasan untuk menentukan perbaikan serta penyempurnaan tindakan selanjutnya. Terdapat dua hal pokok dalam penelitian tindakan yaitu perbaikan dan keterlibatan. Hal ini akan mengarahkan tujuan penelitian tindakan ke dalam tiga area yaitu; (1) untuk memperbaiki praktik; (2) untuk pengembangan profesional dalam arti meningkatkan pemahaman para praktisi terhadap praktik yang dilaksana- kannya; serta (3) untuk memperbaiki keadaan atau situasi di mana praktik tersebut dilaksanakan. Dalam bidang pendidikan, khususnya dalam praktik pembelajaran, penelitian tindakan berkembang menjadi Penelitian Tindakan Kelas (PTK) atau Classroom Action Reserach (CAR).

PTK adalah penelitian tindakan yang dilaksanakan di dalam kelas ketika pembelajaran berlangsung. PTK dilakukan dengan tujuan untuk memperbaiki atau meningkatkan kualitas pembelajaran. PTK berfokus pada kelas atau pada proses pembelajaran yang terjadi di dalam kelas. Suharsimi (2016) menjelaskan bahwa PTK merupakan gabungan definisi dari tiga kata yaitu Penelitian, Tindakan, dan Kelas. Penelitian dapat diartikan sebagai kegiatan mencermati suatu obyek dengan menggunakan cara dan metodologi tertentu untuk memperoleh data atau 
informasi yang bermanfaat dalam memecahkan suatu masalah. Tindakan yaitu sesuatu gerak kegiatan yang sengaja dilakukan dengan tujuan tertentu. Tindakan yang dilaksanakan dalam PTK berbentuk suatu rangkaian siklus kegiatan. Sedangkan Kelas yaitu sekelompok siswa yang dalam waktu yang sama, menerima pelajaran yang sama dari guru yang sama pula. Siswa yang belajar tidak hanya terbatas dalam sebuah ruangan kelas saja, melainkan dapat juga ketika siswa sedang melakukan karyawisata, praktikum di laboratorium, atau belajar tempat lain di bawah arahan guru (Prahani et al, 2021).

Berdasarkan pengertian di atas, komponen yang terdapat dalam sebuah kelas yang dapat dijadikan sasaran PTK adalah siswa, guru, materi pelajaran, peralatan atau sarana pendidikan, hasil pembelajaran (afektik, psikomotor), lingkungan belajar, dan pengelolaan. Seorang guru dapat menemukan masalah penelitian tindakan kelas berdasarkan komponen tersebut (Rahmawati et al, 2021). PTK merupakan suatu bentuk penelitian yang melekat pada guru, yaitu mengangkat masalah-masalah aktual yang dialami oleh guru di lapangan. Dengan melaksanakan PTK, diharapkan guru memiliki peran ganda yaitu sebagai praktisi dan sekaligus peneliti. Dengan demikian dapat disimpulkan bahwa PTK adalah suatu kegiatan penelitian yang dilakukan guru di dalam kelasnya dengan permasalahan diperoleh dari kegiatan refleksi diri dan disertai suatu tindakan dengan tujuan untuk menyelesaikan masalah tersebut atau meningkatkan mutu pembelajaran yang dilakukan (Nugraheni et al, 2021).

Kegiatan workshop penyusunan proposal Penelitian Tindakan Kelas (PTK) yang diberikan kepada guru-guru SMA Negeri 2 Paloh diharapkan dapat menambah wawasan guruguru dalam melaksanakan PTK di kelas dan jenjang sekolah masing-masing. Pelatihan ini pada khususnya diharapkan dapat meningkatkan atau memperbaiki kinerja belajar siswa di sekolah, meningkatkan mutu proses pembelajaran di kelas, meningkatkan kualitas penggunaan media, alat bantu belajar, dan sumber belajar lainnya, meningkatkan, memperbaiki maupun menjaga kualitas prosedur dan alat evaluasi yang digunakan untuk mengukur proses dan hasil belajar siswa. Selain itu, workshop juga dimaksudkan untuk membantu guru-guru dalam upaya peningkatan atau perbaikan terhadap masalah-masalah pendidikan anak di sekolah serta peningkatan dan perbaikan terhadap kualitas penerapan kurikulum dan pengembangan kompetensi siswa di sekolah. Pelatihan pembuatan proposal Penelitian Tindakan Kelas (PTK) sangat dibutuhkan oleh para guru untuk memenuhi kewajibannya sebagai tenaga pendidik.

Proposal sendiri berasal dari bahasa inggris, to popose yang artinya mengajukan yang secara sederhana bisa diartikan sebagai bentuk pengajuan atau permohonan. Penelitian Tindakan Kelas (PTK) sebenarnya merupakan pengembangan dari penelitian tindakan (action research). Kemmis dan Taggart dalam menerangkan bahwa penelitian tindakan (action research) adalah suatu bentuk penelitian refleksi diri yang dilakukan oleh para partisipan dalam situasi sosial (termasuk pendidikan) untuk memperbaiki praktik yang dilakukan sendiri. Penelitian tindakan kelas merupakan suatu pencermatan terhadap kegiatan belajar berupa sebuah tindakan, yang sengaja dimunculkan dan terjadi dalam sebuah kelas secara bersamaan (Wibowo, 2016). Lebih lanjut, menurut Hopkins, PTK dapat didefinisikan sebagai bentuk kajian yang bersifat reflektif, yang dilakukan oleh pelaku tindakan untuk meningkatkan kemantapan rasional dari tindakantindakannya dalam melaksanakan tugas dan memperdalam pemahaman terhadap kondisi dalam praktek pembelajaran. Dari pendapat beberapa pakar pendidikan seperti disampikan di atas, maka dapat disimpulkan bahwa Penelitian Tindakan Kelas adalah penelitian yang dilakukan oleh guru di dalam kelasnya sendiri melalui refleksi diri, dengan tujuan untuk memperbaiki kinerjanya sebagai guru, sehingga hasil belajar peserta didik menjadi meningkat. Dari latar belakang tersebut, rumusan masalah pada artikel ini yaitu terkait pada program pengabdian masyarakat yakni bagaimana membuat proposal PTK pada kegiatan workshop penulisan proposal penelitian tindakan kelas untuk guru di SMA Negeri 2 Paloh Kabupaten Sambas. Tujuan kegiatan pengabdian masyarakat ini agar para guru-guru dapat menulis proposal penelitian tindakan kelas dengan baik guna perbaikan dan tindak lanjut pendidikan dan pembelajaran kedepannya supaya pendidikan dan pembelajaran dapat dilakukan dengan sistematis, runtut, dan baik. 


\section{METODE}

Metode pelaksanaan, langkah-langkah dalam melaksanakan program pengabdian kepada masyarakat dalam bentuk program workshop penelitian tindakan kelas diantaranya yaitu:

a. Menghubungi pihak sekolah terkait akan dilaksanakannya workshop, dalam hal ini menghubungi pihak SMA Negeri 2 Paloh.

b. Survei tempat pelaksanaan yang akan dipakai dalam kegiatan sosialisasi.

c. Menemui pihak sekolah terkait menjelaskan latar belakang dan tujuan program yang akan disosialisasikan.

d. Permohonan izin kepada pihak sekolah terkait akan dilaksanakannya workshop.

e. Pengurusan administrasi, dalam hal ini yaitu surat-menyurat yang akan digunakan dalam perizinan dan lain-lain.

f. Penyiapan kebutuhan dan akomodasi seperti konsumsi dan lain-lain.

g. Persiapan ruangan maupun gedung yang akan digunakan.

h. Pada saat pelaksanaan, kegiatan tersebut dibuka dan ada perkenalan dari pihak dosen dan pihak sekolah.

i. Presentasi dari pihak dosen dan dilanjutkan dengan pembuatan outline proposal Penelitian Tindakan Kelas (PTK).

j. Pada hendak kegiatan akan ditutup, dilaksanakannya foto bersama kepada guru-guru SMA Negeri 2 Paloh untuk bukti dokumentasi.

k. Berpamitan dengan kepala sekolah serta guru-guru yang ada di SMA Negeri 2 Paloh.

\section{HASIL DAN PEMBAHASAN}

Berikut ini adalah hasil dari program workshop penulisan proposal penelitian tindakan kelas (PTK) yang dilaksanakan di SMA Negeri 2 Paloh:

\subsection{Pemberian materi proposal Penelitian Tindakan Kelas (PTK) oleh Pihak Dosen}

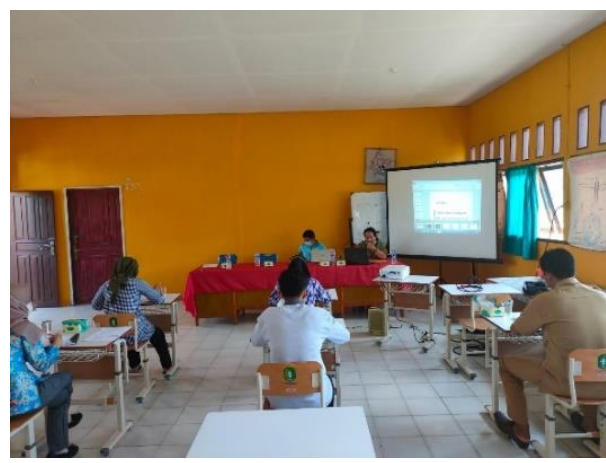

Gambar 1. Pihak dosen memberikan materi kepada pihak guru

Pada gambar tersebut, kita dapat melihat guru-guru di SMA Negeri 2 Paloh sedang menerima materi yang diberikan oleh pihak dosen. Materi yang diberikan oleh pihak dosen dapat diterima dengan baik, dengan alat-alat bantu berupa proyektor dan laptop, dosen dengan mudah menyampaikan materi dan berjalan dengan kondusif. Hal terseubt dilakukan dengan tujuan agar guru-guru dapat memahami setiap materi-materi yang disampaikan. Dengan menggunakan alat bantu, hal tersebut membantu para dosen sebagai pemateri dalam memberikan stimulus kepada guru terkait bagaimana penulisan proposal penelitian tindakan kelas yang baik, agar dapat dipahami oleh setiap guru-guru yang mengikuti workshop. Selain itu juga, dalam hal ini dapat mengefisiensikan waktu, terutama di dalam menjelaskan dan menggambarkan format penulisan proposal penelitian tindakan kelas. Apabila hanya disampaikan secara langsung tanpa alat bantu, hal itu pastinya akan sulit bagi guru dalam melihat format penulisan yang baik dan benar. 


\subsection{Pihak guru sedang mengerjakan outline proposal Penelitian Tindakan Kelas (PTK)}

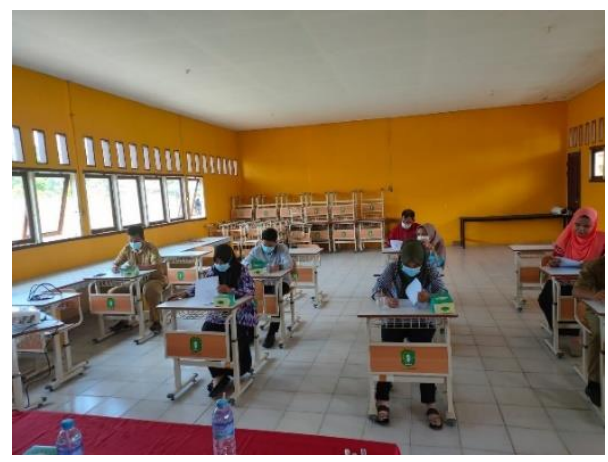

Gambar 2. Pihak guru mengerjakan outline proposal PTK

Pada gambar tersebut, kita dapat melihat bahwa guru-guru di SMA Negeri 2 Paloh sedang mengerjakan outline proposal PTK. Hal ini dilakukan agar guru-guru dapat mengimplementasikan materi yang disampaikan oleh dosen, agar guru-guru dapat memahami bagaimana cara membuat proposal yang baik, agar dapat digunakan untuk pengembangan pembelajaran kedepannya agar menjadi lebih baik lagi. Tahap ini dilakukan juga bertujuan agar guru-guru dapat mencoba membuat proposal yang baik, dalam hal ini nilai-nilai seperti mandiri dilakukan, agar guru-guru kedepannya terbiasa di dalam membuat proposal penelitian tindakan kelas, sehingga guru-guru tidak lagi kebingungan dalam membuat proposal, tetapi mereka akan terbiasa, dan pembelajaran diharapkan dapat terus dilakukan suatu perubahan yang lebih baik lagi.

\subsection{Dokumentasi antara pihak dosen dan pihak guru}



Gambar 3. Dokumentasi antara pihak dosen dan pihak guru

Dari gambar diatas, bahwa kegiatan tersebut selesai dilaksanakan, lalu dilanjutkan dengan dokumentasi antara pihak dosen dan pihak guru. Dokumentasi ini dilakukan sebagai bukti bahwa kegiatan workshop PTK dapat berjalan dengan baik, serta disimpan sebagai arsip untuk pihak guru maupun pihak dosen yang terlibat dalam kegiatan ini. Selain itu, dokumentasi ini juga dilakukan untuk pihak dosen, dimana dalam hal ini, dosen membutuhkan dokumentasi sebagai bukti bahwa ia telah melakukan kegiatan pengabdian kepada masyarakat, serta menjadikan hal ini sebagai nilai bagi beban kerja dosen (BKD). Bagi guru, hal ini dapat dijadikan sebagai laporan bahwa sekolah tersebut telah dilakukan workshop terkait penulisan proposal penelitian tindakan kelas, agar kedepannya, instansi tersebut dapat dilakukan perubahan dan tindak lanjut kepada hal yang lebih baik lagi terutama dalam menunjang pendidikan yang lebih baik. 


\section{KESIMPULAN}

Kegiatan pengabdian kepada masyarakat mengenai workshop penulisan proposal penelitian tindakan kelas untuk guru di SMA Negeri 2 Paloh Kabupaten Sambas, sudah berjalan dengan lancar. Kegiatan pengabdikan kepada masyarakat mengenai workshop penulisan proposal penelitian tindakan kelas untuk guru di SMA Negeri 2 Paloh Kabupaten Sambas, mendapat respon yang antusias dari pihak sekolah dan menginginkan kembali diadakannya kegiatan-kegiatan sosialisasi seperti ini, karena dapat menambah wawasan terutama dalam penulisan proposal penelitian tindakan kelas (PTK) agar kedepannya pembelajaran dapat dikembangkan menjadi lebih baik lagi dibandingkan pada sebelumnya.

\section{DAFTAR PUSTAKA}

Barnawi, J. R. R. (2019). Meningkatkan Kemampuan Guru dalam Menyusun Penelitian Tindakan Kelas Melalui Kegiatan Workshop Improve Teachers ' Ability in Compiling Classroom Action Research Through Workshop Activities. ARJI: Action Research Journal Indonesia, 1(2), 1-12. http://journal.ummat.ac.id/index.php/JCES

Febrilia, B. R. A., Juliangkary, E., Yuliyanti, S., Prasetya, D. S. B., Pujilestari, \& Setyawati, D. U. (2020). Workshop Penulisan Artikel Ilmiah Bagi Guru MIPA SMK Islam Al-Abhariyah Scientific Article Writing Workshop for MIPA Teachers at Al-Abhariyah Islamic Vocational School. Jurnal Panrita Abdi, 4(1), 69-76. http://journal.unhas.ac.id/index.php/panritaabdi

Jaedun, A. (2011). Pengembangan Profesionalisme Guru Melalui Penulisan Karya Tulis Ilmiah. Seminar Karya Tulis Ilmiah Dan Penelitian TIndakan Kelas, 4(6), 0-14.

Nugraheni, L., Fathonah, N., Astutik, E. P., Sulistyaningtyas, A. D., \& Susilowati, E. (2021). Workshop Penulisan Sitasi Dan Referensi Artikel Ilmiah Bagi Guru Sman 1 Dawarblandong. Jurnal Pengabdian Kepada Masyarakat (JPKM) - Aphelion, 1(2), 177. https://doi.org/10.32493/jpka.v1i2.8618

Prahani, B. K., Tsuroyya, T., Kohar, A. W., \& Setiawan, S. (2020). Workshop Penulisan Artikel Ilmiah Moda Daring Bagi Guru SMA Kota Surabaya Pada Masa Pandemi Covid-19. Dedication: Jurnal Pengabdian Masyarakat, 4(2), 109-118. https://doi.org/10.31537/dedication.v4i2.358

Rahmawati, T. D., Prasetyo, E., \& Nuwa, G. (2021). Workshop Penulisan Ptk Dan Publikasi Artikel Ilmiah Untuk Guru Di Sma Negeri 1 Nita. Jurnal Abdimas Ilmiah Citra Bakti, 2(1), 18-23. https://doi.org/10.38048/jailcb.v2i1.183

WIbowo, E. A. A. (2016). Aplikasi Mobile Learning Berbasis Android. Unnes Journal of Mathematics, 5(2), 108-117. https://doi.org/10.15294/ujm.v5i2.13119 